\title{
Effects of inorganic minerals replaced by complexed glycinates on growth, blood profiles, immune responses, intestinal morphology, and mineral excretion in piglets
}

\section{Xun Pei}

Zhejiang University

Geng Wang

Zhejiang University

Lujie Liu

Zhejiang University

Wanjing Sun

Zhejiang University

\section{Zhiping Xiao}

Zhejiang University

\section{Wenjing Tao}

Zhejiang University

Minqi Wang ( $\nabla$ wangmq@zju.edu.cn )

Zhejiang University https://orcid.org/0000-0001-5658-2896

Mingyan Huai

BASF SA

\section{Lily Li}

BASF SA

\section{Wolf Pelletier}

BASF SE

\section{Research}

Keywords: trace minerals, piglets, bioavailability, metal pollution

Posted Date: June 18th, 2020

DOl: https://doi.org/10.21203/rs.3.rs-35495/v1

License: (9) This work is licensed under a Creative Commons Attribution 4.0 International License. 

1 Effects of inorganic minerals replaced by complexed glycinates on growth,

2 blood profiles, immune responses, intestinal morphology, and mineral excretion in piglets

4

5 Xun Pei ${ }^{\mathrm{a}}$, Geng Wang ${ }^{\mathrm{a}}$, Lujie Liu ${ }^{\mathrm{a}}$, Wanjing Sun ${ }^{\mathrm{a}}$, Zhiping Xiao ${ }^{\mathrm{a}}$, Wenjing Tao ${ }^{\mathrm{a}}$, Minqi

6 Wang, ${ }^{\text {a, }}$, Mingyan Huai ${ }^{\mathrm{b}}$, Lily Li ${ }^{\mathrm{b}}$, and Wolf Pelletier ${ }^{\mathrm{c}}$

7

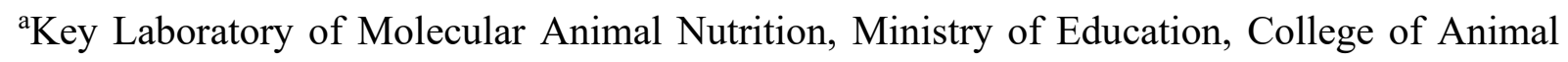

$9 \quad$ Science, Zhejiang University, Hangzhou 310058, P. R. China

${ }^{\mathrm{b}}$ BASF SEA Pte Ltd, Singapore 038987, Singapore

'BASF SE, Lampertheim 68623, Germany

\section{${ }^{*}$ Corresponding author}

Co-authors: Xun Pei: pxpeixun@zju.edu.cn

Lujie Liu: liulj@zju.edu.cn

Wanjing Sun: sunwanjing@zju.edu.cn

Zhiping Xiao: xiaozp@zju.edu.cn 
Abbreviations: ITM = inorganic trace mineral, GCM = glycine-complexed trace mineral, $\mathrm{OTM}=$ organic trace mineral, $\mathrm{BW}=$ body weight, $\mathrm{TiO}_{2}=$ titanium dioxide, $\mathrm{ATTD}=$ apparent total tract digestibility, $\mathrm{T} 1=$ treatment 1 , and so on, $\mathrm{ALP}=$ alkaline phosphatase, $\mathrm{Alb}=$ albumin, $\mathrm{Fer}=$ ferritin, $\mathrm{TIBC}=$ total iron binding capacity, $\mathrm{TP}=$ total protein, $\mathrm{CP}=$ ceruloplasmin, $\mathrm{TRF}=$ transferrin, $\mathrm{Ig}=$ immunoglobulin, $\mathrm{C} 3=$ complement 3 , and so on, $\mathrm{VH}=$ villous height, $\mathrm{CD}=$ crypt depth, $\operatorname{sIg} \mathrm{A}=$ secretory immunoglobulin $\mathrm{A}$ 
Abstract:

BACKGROUND: The effects of inorganic trace minerals (ITM) replaced by low-dose glycine-complexed trace minerals (GCM) on growth, serum parameters, immunity, intestinal morphology, and mineral excretion in piglets were investigated. One hundred and twenty-eight weaned piglets $(14.18 \pm 0.33 \mathrm{~kg}$ body weight $(\mathrm{BW}))$ were randomly assigned to 4 treatments with 4 replicates, 8 piglets per replicate. Treatments consist of: (T1) basal diet $+100 \%$ inorganic trace mineral (ITM) as the control group (20 ppm Cu, $150 \mathrm{ppm} \mathrm{Fe}, 150 \mathrm{ppm} \mathrm{Zn}$, and $30 \mathrm{ppm}$ Mn from sulfates); (T2) basal diet $+50 \%$ ITM $(\mathrm{Cu}, \mathrm{Fe}, \mathrm{Zn}$, and Mn from sulfates, $50 \%$ of control $)+50 \%$ organic trace minerals $(\mathrm{OTM}, \mathrm{Cu}, \mathrm{Fe}, \mathrm{Zn}$, and $\mathrm{Mn}$ from glycine complexed trace minerals $(\mathrm{GCM}), 50 \%$ of control); (T3) basis diet + 50\% OTM from GCM; (T4) basal diet + 70\% OTM from GCM. The feeding period lasted $28 \mathrm{~d}$ and was divided into 2 stages ( 0 to $14 \mathrm{~d}$ and 15 to $28 \mathrm{~d}$ ). After feeding trial, 6 pigs per treatment were randomly selected to slaughter for sampling.

RESULTS: Average daily gain, feed intake, and G:F were not affected by dietary treatments during the overall period. During the second, and the overall feeding phases, the digestibility of $\mathrm{Zn}$ and Fe in T3 and T4 was higher than that of $\mathrm{T} 1(P<0.05)$. The concentration of serum ferritin in $\mathrm{T} 2$ was significantly higher than $\mathrm{T} 3$ and $\mathrm{T} 4$. Serum immunoglobulin A concentration in the ileal mucosa of T2 was higher than that of T1 $(P<0.05)$, and the higher duodenum villus height was observed in T4 compared with the rest treatments $(P<0.05)$. The lowest trace mineral excretion was overserved in $\mathrm{T} 3(P<0.01)$; in addition, the urinary concentrations of $\mathrm{Zn}$ and $\mathrm{Fe}$ in T2 were lower than that in $\mathrm{T} 1(P<0.05)$.

CONCLUSION: These results indicate that GCM have higher bioavailability than ITM, and that supplementation of low-dose GCM to replace full dose ITM could reduce mineral excretion without affecting performance, blood profiles, immune responses, and intestinal morphology in piglets.

Key words: trace minerals, piglets, bioavailability, metal pollution 
Introduction

Microminerals fulfill a central role in many metabolic processes throughout the body. Supplementing adequate microminerals in swine diets requirements is crucial for growth, reproduction, immune system development, and antioxidant capacity [1,2]. Even though NRC (2012) further states that the innate portion of the diet is included within the listed requirements, it is a common practice that micromineral premixes and diets are formulated while neglecting the contribution of these innate microminerals. This is mainly due to the unknown bioavailability and variable concentrations in grains and other feedstuffs [3]. In practice, most commercial premixes exceed the NRC (2012) requirements, and consequently, microminerals in many diets often exceed the requirements of pigs.

One apparent disadvantage of over supplying microminerals to the animals is the environmental consequence of elevated minerals excretions. The excess trace minerals emitted are difficult to collect for centralized treatment, and could leach to the soil and water sources around the farm and potentially cause heavy metal pollution. It is rather urgent to find solutions to reduce the amount of trace minerals used from the dietary sources, which may offer a direct and effective method to reduce heavy metal pollution from livestock production.

Without affecting the growth and health of the animals, the most plausible solution to reduce the excretion of trace minerals is to use mineral sources with a superior bioavailability, which reduces dietary mineral supplementation. So far, previous studies have shown that the bioavailability of organic trace minerals (OTM) as complexed glycinate form is higher than that of frequently-used inorganic trace minerals [4-7]; however, most studies focused on replacing one or two elements, and data on totally replacing ITM (i.e., $\mathrm{Fe}, \mathrm{Cu}, \mathrm{Mn}$ and $\mathrm{Zn}$ ) by its respective OTM at different levels in diets are limited. This study was designed to evaluate the effects of ITM replaced by lower-dose glycine-complexed trace minerals (GCM) on growth performance, serum biochemical 
parameters, immunity, intestinal morphology, and fecal mineral excretion in piglets.

\section{Materials and methods}

\section{Experiment Design and Animal Management}

The site and piglets of the feeding trial were provided by Anji Zhengxin Breeding Farm (Huzhou, China). A total of 128 pigs with an initial $\mathrm{BW}$ of $14.18 \mathrm{~kg}(\mathrm{SEM}=0.33)$ were allotted to 4 dietary treatments in a randomized complete block design with 4 replicates (pens) and 8 animals per pen. All piglets were 35 days old and weaned at 23 days of age. Pigs were acclimatized for 5 days. The formal feeding trial started when pigs were 40 days old and lasted for 28 days, which was divided into two phases. Phase I was 0 to $14 \mathrm{~d}$ and phase II was 14 to $28 \mathrm{~d}$. The basal diet (Table 1) was formulated according to the common-used trace mineral dosage of $15-30 \mathrm{~kg}$ piglets in Chinese intensive pig farms (above NRC (2012) recommendation) (Table 2). The specific mineral supplemental doses and analytical values of trace minerals in 4 treatments were provided in Table 2. Titanium dioxide $\left(\mathrm{TiO}_{2}\right)$ was added to the diet as an indicator for determining the apparent total tract digestibility (ATTD) of trace minerals. Inorganic trace minerals $\left(\mathrm{Cu}, \mathrm{Fe}, \mathrm{Zn}\right.$, and $\mathrm{Mn}$ from $\mathrm{CuSO}_{4} \cdot 5 \mathrm{H}_{2} \mathrm{O}, \mathrm{FeSO}_{4} \cdot \mathrm{H}_{2} \mathrm{O}, \mathrm{ZnSO}_{4} \cdot \mathrm{H}_{2} \mathrm{O}$, and $\mathrm{MnSO}_{4} \cdot \mathrm{H}_{2} \mathrm{O}$ ) were used in treatment $1(\mathrm{~T} 1$, as control), and the respective mineral supplementation levels match commercially recommended concentrations of $20 \mathrm{mg} \mathrm{Cu}, 150 \mathrm{mg} \mathrm{Fe}, 150 \mathrm{mg} \mathrm{Zn}, 30 \mathrm{mg} \mathrm{Mn}$ per $\mathrm{kg}$ feed, respectively. Treatment 2 (T2) consists of 50\% ITM of control and 50\% OTM including $\mathrm{Cu}, \mathrm{Fe}, \mathrm{Zn}$ and $\mathrm{Mn}$ provided by GCM (BASF SE, Germany) at concentrations of 10,75, 75, $15 \mathrm{mg} \mathrm{kg}^{-1}$, respectively. Treatment 3 (T3) and treatment 4 (T4) used lower levels of GCM (50\% and 70\% of control, respectively), which was described in $\mathrm{T} 2$ as mineral sources for the diet.

Table 2. Supplemental levels and analytical values of trace minerals in four treatments

\begin{tabular}{|c|c|c|c|c|}
\hline & Treatment 1 & Treatment 2 & treatment 3 & Treatment 4 \\
\hline Item & $100 \%$ ITM & $\begin{array}{c}50 \% \text { ITM }+50 \% \\
\text { GCM }\end{array}$ & $50 \%$ GCM & $70 \%$ GCM \\
\hline
\end{tabular}




\begin{tabular}{lcccc}
\hline Supplemental & & & & \\
levels, mg kg-1 & & & \\
$\mathrm{Cu}$ & 20 & 20 & 10 & 14 \\
$\mathrm{Fe}$ & 150 & 150 & 75 & 105 \\
$\mathrm{Zn}$ & 150 & 150 & 75 & 105 \\
$\mathrm{Mn}$ & 30 & 30 & 15 & 21 \\
Analytical values & & & & \\
(0 to 14 d), mg & & & & \\
$\mathrm{kg}^{-1}$ & & & & \\
$\mathrm{Cu}$ & 27.74 & 27.04 & 17.36 & 21.42 \\
$\mathrm{Fe}$ & 256.56 & 253.93 & 179.45 & 211.07 \\
$\mathrm{Zn}$ & 183.24 & 182.11 & 106.78 & 139.04 \\
$\mathrm{Mn}$ & 42.72 & 43.74 & 28.08 & 34.79 \\
$\mathrm{Analytical} \mathrm{values}$ & & & & \\
$(15$ to 28d), mg & & & & \\
$\mathrm{kg}-1$ & & & \\
$\mathrm{Cu}$ & 28.83 & 28.21 & 18.35 & 22.67 \\
$\mathrm{Fe}$ & 214.83 & 216.22 & 142.06 & 172.87 \\
$\mathrm{Zn}$ & 179.97 & 179.84 & 103.57 & 134.74 \\
$\mathrm{Mn}$ & 42.73 & 43.72 & 28.43 & 34.12 \\
\hline
\end{tabular}

Pens used in the feeding trial had hard concrete slotted flooring and were equipped with nipple drinkers and

finishing the feeding trial, 6 pigs per treatment (at least one pig per pen) were randomly selected for slaughtering and sampling. Average daily gain (ADG), average daily feed intake (ADFI), and gain to feed ratio (G:F) were calculated at the end of the trial.

\section{Sample Collecting}

Fresh feces collection was carried out on the last three days of each phase on the pen basis, mixed and stored feces sample of each phase at $-80^{\circ} \mathrm{C}$ for later analysis. Before slaughtering, blood samples were collected by syringe from the precaval vein of selected pigs. Serum was obtained by centrifuging at $1260 \times \mathrm{g}$ at $4{ }^{\circ} \mathrm{C}$ for 10 
syringe and stored at $-80^{\circ} \mathrm{C}$. The small intestine was separated and dissected. The segments of middle duodenum and jejunum were separated for a length of $2 \mathrm{~cm}$ with flushing by sterile saline solution and stored in $4 \%$ paraformaldehyde under $4{ }^{\circ} \mathrm{C}$. Additional jejunum segment was isolated and stored in $2.5 \%$ malondialdehyde under $4{ }^{\circ} \mathrm{C}$. Duodenum, jejunum and ileum mucosa were scraped and collected using the clean glass slides and stored at $-80^{\circ} \mathrm{C}$.

\section{Serum Parameters and Immune Response Analysis}

Serum alkaline phosphatase (ALP), albumin (Alb), serum ferritin (Fer), total iron binding capacity (TIBC), total protein (TP), and urea were determined by an automated biochemical analyzer (Olympus AU5831, Tokyo, Japan). The concentrations of ceruloplasmin (CP) and transferrin (TRF) were measured using the commercial kits (Jiancheng Bioengineering Institute, Nanjing, China) and ELISA kits (Jiancheng Bioengineering Institute, Nanjing, China), respectively. To assess the immune function, serum immunoglobulin A ( $\operatorname{Ig} \mathrm{A})$, immunoglobulin G (IgG), immunoglobulin M (IgM), complement 3 (C3) and complement 4 (C4) concentrations were detected with immunoturbidimetry by commercial kits (Jiancheng Bioengineering Institute, Nanjing, China). Concentrations of serum inflammatory factors IL-6, IL-10, and TNF- $\alpha$ were determined by ELISA kits (Beijing 4A Biotech Co., Ltd, Beijing, China). The jejunum and ileum mucosa were ground on ice by a glass grinder to make a $10 \%$ homogenate for the detection of sIgA concentration, and the procedure was also carried out according to the instruction of commercial kit (Jiancheng Bioengineering Institute, Nanjing, China).

\section{Mineral Measurement and ATTD Calculation}

The trace mineral concentrations in feed, feces and urine samples were determined by atomic flame absorption spectrometry (ICE-3500, Thermo Crop., USA). Before the analysis, feces and feed samples were dried at $65{ }^{\circ} \mathrm{C}$ for $48 \mathrm{~h}$, and then pulverized by a grinder and passed through a 60 mesh sieve $(0.25 \mathrm{~mm})$ to 
achieve homogenous samples. The ground feces and feed sample were digested using the method described as follows: $1 \mathrm{~g}$ of sample was placed in a crucible and ashed at $550{ }^{\circ} \mathrm{C}$ for $4 \mathrm{~h}$ in muffle furnace until it became off-white powder, and $10 \mathrm{ml}$ of $10 \%$ hydrochloric acid was added for dissolving. After filtration, the filtrate was diluted to $100 \mathrm{ml}$ with distilled water. Urine sample was thawed and treated by microwave wet digestion as follows: $1 \mathrm{ml}$ sample was mixed with $6 \mathrm{ml}$ nitric acid for 3 minutes at $120^{\circ} \mathrm{C}$ in a microwave digestion system, $120{ }^{\circ} \mathrm{C}$ for 8 minutes, and kept at $230{ }^{\circ} \mathrm{C}$ for 4 minutes until a pale yellow solution appeared, then removed the residual acid, and finally dilute with distilled water to $50 \mathrm{ml}$. The absorption wavelengths of $\mathrm{Cu}, \mathrm{Zn}, \mathrm{Fe}$ and $\mathrm{Mn}$ in the flame of air-acetylene combustion were $324.8 \mathrm{~nm}, 213.9 \mathrm{~nm}, 248.3 \mathrm{~nm}$ and $279.5 \mathrm{~nm}$, respectively. The ATTD of trace minerals was calculated as follows: ATTD $(\%)=100 *\left(1-\mathrm{I}_{\mathrm{r}} * \mathrm{~N}_{\mathrm{f}} /\left(\mathrm{I}_{\mathrm{f}} * \mathrm{~N}_{\mathrm{r}}\right)\right)$; $\mathrm{I}_{\mathrm{r}}$ : the content of indicator in feed (\%); $\mathrm{I}_{\mathrm{f}}$ : the content of indicator in feces (\%); $\mathrm{N}_{\mathrm{r}}$ : the content of trace minerals in feed (\%); $\mathrm{N}_{\mathrm{f}}$ : the content of trace minerals in feces $(\%)$.

\section{Intestinal Morphology Analysis and Scanning Electron Microscopy (SEM)}

After adequate fixation, small intestine samples were embedded in paraffin, cut cross-section of $5 \mu \mathrm{m}$ and then stained with hematoxylin and eosin (H\&E, Solarbio Science \& Technology Co., Ltd, Beijing, China). Images were acquired using a DM3000 microscope (Leica, Wetzlar, Germany). Villous height (VH) and crypt depth (CD) were measured using Image-Pro software (Media Cybernetics, MD, USA) as previously reported $[8,9]$. All images and measurements were performed by the same person using the same microscope. The jejunum segment in glutaraldehyde was cut into a small rectangle before osmic acid fixation. Trimmed jejunum samples were rinsed three times with PBS and then fixed with $1 \% \mathrm{OsO}_{4}$ for $1.5 \mathrm{~h}$, then osmic acid was discarded and dehydrated in a graded series of ethanol $(30 \%, 50 \%, 70 \%, 80 \%, 90 \%, 95 \%$, and $100 \%)$ for 20 min at each step and then transferred into a mixture of alcohol and iso-amyl acetate (v:v $=1: 1)$ for $30 \mathrm{~min}$ and iso-amyl acetate for $1 \mathrm{~h}$. The specimens were then dehydrated in a Hitachi Model HCP-2 critical point dryer with liquid 
FASEM (HITACHI, Japan).

151

152

\section{Metal Transporter mRNA Expression in Duodenum}

An analysis of duodenum metal transporter gene expression was conducted as previously described by Huang [10]. The duodenal mucosa was ground by liquid nitrogen and then added to the TRIzol reagent (Invitrogen, Carlsbad, California, USA) for RNA extraction. The RNA quantity and quality were determined using a NanoDrop 2000 spectrophotometer (Thermo Fisher Scientific, Massachusetts, USA). The cDNA was synthesized with the PrimeScript RT reagent kit with gDNA Eraser (TAKARA, Dalian China) according the following procedure: $2 \mu \mathrm{g}$ RNA was used to erase gDNA at $42^{\circ} \mathrm{C}$ for $2 \mathrm{~min}$, and the reverse transcription was conducted at $37{ }^{\circ} \mathrm{C}$ for $15 \mathrm{~min}$ and $85{ }^{\circ} \mathrm{C}$ for $5 \mathrm{~s}$. Real-Time PCR was performed on a CFX96TM Real-Time system (BioRad, Hercules, CA, USA) in a total volume of $25 \mu \mathrm{L}$, which consists of $12.5 \mu \mathrm{L}$ SYBR Premix EX Taq (TAKARA), $0.5 \mu \mathrm{L}$ forward primer $(10 \mu \mathrm{M}), 0.5 \mu \mathrm{L}$ reverse primer $(10 \mu \mathrm{M}), 2 \mu \mathrm{L}$ cDNA and $9.5 \mu \mathrm{L}$ double-distilled water. The primer sequences for ZnT1, Fpn1, Ctr1, DMT1 and $\beta$-actin were designed with primer 5.0 (Table 3) and synthesized in Tsingke Biological Technology Co., Ltd. The protocol of PCR consisted of $30 \mathrm{~s}$ at $95{ }^{\circ} \mathrm{C}$ and followed 40 cycles of $95{ }^{\circ} \mathrm{C}$ for $5 \mathrm{~s}$ and $58{ }^{\circ} \mathrm{C}$ for $30 \mathrm{~s}$. $\beta$-actin was used as a housekeeping gene and the relative mRNA expression was calculated using the $2^{-\Delta \Delta C t}$ method [11].

Table 3. Primers for gene expression using real-time PCR

\begin{tabular}{lccc}
\hline \hline Gene & Accession number & Primer sequence (5' to 3') & Size(bp) \\
\hline ZnT1 & NM_001139470.1 & F: ATCACAGCGGCTTCGGCAAC & 155 \\
& & R: GGTCTCCTCCTGGTCGGTTCC & 121 \\
Fpn1 & NM_001128440.1 & F: GAGCAGCAGCAGCGATAGCAG &
\end{tabular}


Ctr1 NM_214100.3

R: AAGGAGACGAGGAGGCGAAGAC

F: TGGAGGATCGCAGGCGGTATC

DMT1 NM 001128440.1

R: AGCCACCACATACAACACCACATG

F: CCAGGTCATCACCATCGGCAAC

$\beta$-actin $\quad$ DQ845171.1

R: CAGCACCGTGTTGGCGTAGAG

\section{Statistical Analysis}

Data were analyzed by using the one-way analysis of variance (ANOVA) to test homogeneity of variances

via Levene's test and followed with LSD test to determine statistically significant differences among treatments 0.05 .

\section{Results}

\section{Growth Performance}


Table 4. Effect of inorganic trace minerals replaced by glycine complexed trace minerals on growth performance in piglets ${ }^{\dagger}$

\begin{tabular}{lcccccc}
\hline \hline Item & $100 \%$ ITM & $\begin{array}{c}50 \% \text { ITM }+ \\
50 \% G C M\end{array}$ & $50 \%$ GCM & $70 \% G C M$ & SEM & $\begin{array}{c}\text { P - } \\
\text { value }\end{array}$ \\
\hline Initial weight, $\mathrm{kg}$ & 14.60 & 14.94 & 13.66 & 13.53 & 0.33 & 0.374 \\
Middle weight, $\mathrm{kg}$ & 21.97 & 22.82 & 21.50 & 20.78 & 0.39 & 0.331 \\
Final weight, $\mathrm{kg}$ & 31.25 & 32.19 & 30.16 & 29.16 & 0.55 & 0.242 \\
ADG, g & & & & & & \\
0 to $14 \mathrm{~d}$ & 526.79 & 562.50 & 560.27 & 517.86 & 10.33 & 0.321 \\
15 to $28 \mathrm{~d}$ & 662.95 & 669.64 & 618.30 & 598.22 & 13.11 & 0.149 \\
0 to $28 \mathrm{~d}$ & 594.87 & 616.07 & 589.29 & 558.04 & 9.74 & 0.212 \\
ADFI, g & & & & & & \\
0 to $14 \mathrm{~d}$ & $845.54^{\mathrm{ab}}$ & $883.97^{\mathrm{a}}$ & $861.92^{\mathrm{ab}}$ & $819.42^{\mathrm{b}}$ & 8.78 & 0.043 \\
15 to $28 \mathrm{~d}$ & 1198.63 & 1211.67 & 1176.22 & 1134.49 & 21.72 & 0.656 \\
0 to $28 \mathrm{~d}$ & 1022.08 & 1047.82 & 1019.07 & 976.96 & 14.50 & 0.414 \\
G:F, g kg & & & & & & \\
0 to $14 \mathrm{~d}$ & 623.09 & 635.92 & 650.03 & 631.51 & 8.71 & 0.779 \\
15 to $28 \mathrm{~d}$ & $553.30^{\mathrm{a}}$ & $552.94^{\mathrm{a}}$ & $525.27^{\mathrm{b}}$ & $528.18^{\mathrm{b}}$ & 4.47 & 0.012 \\
0 to $28 \mathrm{~d}$ & 581.98 & 588.02 & 578.26 & 571.33 & 3.79 & 0.509 \\
\hline
\end{tabular}

182

'Data are expressed as means of the replicates $(n=4)$. In the same row, values with no letter or the same letter superscripts mean no significant difference $(P>0.05)$, while with different small letter superscripts mean significant difference $(P<0.05)$.

\section{Apparent Total Tract Digestibility of Trace Minerals}

As shown in Table 5, no differences in ATTD of tested minerals were detected in the first period ( 0 to $14 \mathrm{~d}$ );

in the second period and the overall feeding period, the ATTD of zinc and iron in the low-dose GCM treatments

(T3 and T4) were higher than that in the $100 \%$ inorganic treatment (T1).

Table 5. Effect of different levels of trace minerals on minerals apparent total tract digestibility in piglets

\begin{tabular}{lcccccc}
\hline \hline Item & $100 \%$ ITM & $\begin{array}{c}50 \% \text { ITM }+5 \\
0 \% G C M\end{array}$ & $50 \% \mathrm{GCM}$ & $70 \% \mathrm{GCM}$ & SEM & P - value \\
\hline 0 to $14 \mathrm{~d}$ & & & & & & \\
$\mathrm{Cu}(\%)$ & 28.60 & 31.04 & 33.60 & 34.97 & 1.71 & 0.612 \\
$\mathrm{Zn}(\%)$ & 53.50 & 57.23 & 61.07 & 61.55 & 1.47 & 0.175 \\
$\mathrm{Fe}(\%)$ & 35.81 & 38.98 & 45.59 & 46.14 & 2.11 & 0.235 \\
$\mathrm{Mn}(\%)$ & 28.71 & 28.79 & 33.02 & 37.50 & 1.80 & 0.272 \\
15 to $28 \mathrm{~d}$ & & & & & & \\
$\mathrm{Cu}(\%)$ & 26.31 & 31.84 & 31.61 & 34.62 & 1.21 & 0.087 \\
$\mathrm{Zn}(\%)$ & $49.57^{\mathrm{b}}$ & $56.17^{\mathrm{ab}}$ & $60.23^{\mathrm{a}}$ & $60.72^{\mathrm{a}}$ & 1.58 & 0.024 \\
$\mathrm{Fe}(\%)$ & $28.30^{\mathrm{b}}$ & $37.90^{\mathrm{ab}}$ & $45.91^{\mathrm{a}}$ & $47.80^{\mathrm{a}}$ & 2.51 & 0.006 \\
& & & 11 & & &
\end{tabular}




\begin{tabular}{lllllll}
$\mathrm{Mn}(\%)$ & 26.42 & 29.87 & 34.76 & 36.72 & 2.07 & 0.299 \\
0 to $28 \mathrm{~d}$ & & & & & \\
$\mathrm{Cu}(\%)$ & 27.46 & 31.44 & 32.60 & 34.79 & 1.26 & 0.222 \\
$\mathrm{Zn}(\%)$ & $51.54^{\mathrm{b}}$ & $56.70^{\mathrm{ab}}$ & $60.65^{\mathrm{a}}$ & $61.13^{\mathrm{a}}$ & 1.33 & 0.017 \\
$\mathrm{Fe}(\%)$ & $32.05^{\mathrm{b}}$ & $38.44^{\mathrm{ab}}$ & $45.75^{\mathrm{a}}$ & $46.97^{\mathrm{a}}$ & 2.14 & 0.025 \\
$\mathrm{Mn}(\%)$ & 27.57 & 29.33 & 33.89 & 37.11 & 1.62 & 0.138 \\
\hline
\end{tabular}

190

${ }^{\dagger}$ Data are expressed as means of the replicates $(n=4)$. In the same row, values with no letter or the same letter superscripts mean no significant difference $(P>0.05)$, while with different small letter superscripts mean significant difference $(P<0.05)$.

\section{Hematological Response}

Table 6. Effect of inorganic trace minerals replaced by glycine complexed trace minerals on serum parameters in piglets ${ }^{\dagger}$

\begin{tabular}{lcccccc}
\hline \hline Item & $100 \%$ ITM & $\begin{array}{c}50 \% \mathrm{ITM}+ \\
50 \% \mathrm{GCM}\end{array}$ & $50 \% \mathrm{GCM}$ & $\begin{array}{c}70 \% \mathrm{OGC} \\
\mathrm{M}\end{array}$ & SEM & P - value \\
\hline ALP $(\mathrm{U} / \mathrm{L})$ & 243.80 & 231.17 & 251.67 & 248.17 & 10.09 & 0.907 \\
$\mathrm{Alb}(\mathrm{g} / \mathrm{L})$ & 20.02 & 21.60 & 22.30 & 18.98 & 0.67 & 0.288 \\
Fer $(\mu \mathrm{g} / \mathrm{L})$ & $4.00^{\mathrm{ab}}$ & $5.67^{\mathrm{a}}$ & $3.50^{\mathrm{b}}$ & $3.75^{\mathrm{b}}$ & 0.33 & 0.050 \\
$\mathrm{TIBC}(\mu \mathrm{mol} / \mathrm{L})$ & 92.24 & 93.42 & 101.57 & 89.93 & 3.01 & 0.562 \\
$\mathrm{TP}(\mathrm{g} / \mathrm{L})$ & 58.06 & 59.38 & 54.38 & 58.15 & 0.90 & 0.215 \\
$\mathrm{Urea}(\mathrm{mmol} / \mathrm{L})$ & 3.72 & 4.04 & 3.94 & 3.72 & 0.18 & 0.911 \\
$\mathrm{Cp}(\mathrm{U} / \mathrm{L})$ & 46.10 & 44.76 & 37.88 & 39.98 & 2.74 & 0.715 \\
$\mathrm{TRF}(\mathrm{mg} / \mathrm{mL})$ & 2.67 & 3.58 & 2.63 & 3.30 & 0.23 & 0.409 \\
\hline
\end{tabular}

$\dagger$ Data are expressed as means of the replicates $(n=6)$. In the same row, values with no letter or the same letter superscripts mean no significant difference $(P>0.05)$, while with different small letter superscripts mean significant difference $(P<0.05)$.

Table 6 shows the results of serum biochemical indicators tested. The concentration of serum ferritin in T2 was significantly higher than that of T3 and T4 and numerically higher than T1 as well; however, supplemental glycine complexed trace minerals to replace inorganic trace minerals did not affect other serum parameters tested.

\section{Immune Response}




\section{Intestinal Morphology}

The duodenal VH in 70\% GCM treatment was significantly higher than that in other 3 treatments; similarly,

the v/c of T4 was also numerically higher than the other three treatments (Fig. 2D). In the jejunal morphology,

VH and CD of T4 was higher than that of T1, and T3 had the highest v/c though it did not reach the significant were more serried than $\mathrm{T} 1$ and $\mathrm{T} 2$ (Fig. 2C).

\section{Relative Expression of Metal Transporter mRNA}

In Fig. 3, the relative expression of ZnT1 mRNA in T4 was higher $(P<0.05)$ than that in the other three treatments. The relative expression of Fpn1, Ctr1 and DMT1 mRNA were not affected by dietary micromineral treatment.

\section{Minerals Excretion}

Table 7 shows that the amount of trace minerals excreted in urine and feces were positively correlated with the dietary supplemental mineral level. The trace minerals excretion in urine and feces of low-dose treatments (T3 and T4) were lower $(P<0.05)$ than the commercial level minerals treatments (T1 and T2), and the trace minerals excretion in T3 was also lower $(P<0.05)$ than T4. When $50 \%$ of dietary ITM replaced by OTM from 
Table 7. Effect of inorganic trace minerals replaced by glycine complexed trace minerals on minerals excretion in urine and feces ${ }^{\dagger}$

\begin{tabular}{lcccccc}
\hline \hline Item & $100 \% \mathrm{ITM}$ & $\begin{array}{c}50 \% \mathrm{ITM}+5 \\
0 \% \mathrm{GCM}\end{array}$ & $50 \% \mathrm{GCM}$ & $70 \% \mathrm{GCM}$ & $\mathrm{SEM}$ & P - value \\
\hline Urine & & & & & & \\
$\mathrm{Cu}, \mu \mathrm{g} / \mathrm{L}$ & $0.86^{\mathrm{a}}$ & $0.79^{\mathrm{a}}$ & $0.44^{\mathrm{c}}$ & $0.53^{\mathrm{b}}$ & 0.04 & 0.000 \\
$\mathrm{Zn}, \mu \mathrm{g} / \mathrm{L}$ & $1.99^{\mathrm{a}}$ & $1.83^{\mathrm{b}}$ & $0.86^{\mathrm{d}}$ & $1.01^{\mathrm{c}}$ & 0.11 & 0.000 \\
$\mathrm{Fe}, \mu \mathrm{g} / \mathrm{L}$ & $0.50^{\mathrm{a}}$ & $0.42^{\mathrm{b}}$ & $0.24^{\mathrm{d}}$ & $0.30^{\mathrm{c}}$ & 0.02 & 0.000 \\
$\mathrm{Mn}, \mu \mathrm{g} / \mathrm{L}$ & $0.18^{\mathrm{a}}$ & $0.14^{\mathrm{ab}}$ & $0.10^{\mathrm{c}}$ & $0.12^{\mathrm{b}}$ & 0.01 & 0.000 \\
$\mathrm{Feces}$ & & & & & & \\
$\mathrm{Cu}, \mathrm{mg} \mathrm{kg}{ }^{-1}$ & $249.60^{\mathrm{a}}$ & $244.93^{\mathrm{a}}$ & $137.57^{\mathrm{c}}$ & $186.82^{\mathrm{b}}$ & 12.15 & 0.000 \\
$\mathrm{Zn}, \mathrm{mg} \mathrm{kg}{ }^{-1}$ & $1181.45^{\mathrm{a}}$ & $1123.11^{\mathrm{a}}$ & $550.61^{\mathrm{c}}$ & $783.81^{\mathrm{b}}$ & 68.97 & 0.000 \\
$\mathrm{Fe}, \mathrm{mg} \mathrm{kg}{ }^{-1}$ & $1663.33^{\mathrm{a}}$ & $1597.89^{\mathrm{a}}$ & $775.43^{\mathrm{c}}$ & $1081.81^{\mathrm{b}}$ & 97.91 & 0.000 \\
$\mathrm{Mn}, \mathrm{mg} \mathrm{kg}^{-1}$ & $358.67^{\mathrm{a}}$ & $383.95^{\mathrm{a}}$ & $198.87^{\mathrm{c}}$ & $266.19^{\mathrm{b}}$ & 19.61 & 0.000 \\
\hline
\end{tabular}

Data are expressed as means of the replicates $(n=4)$. In the same row, values with no letter or the same letter superscripts mean no significant difference $(P>0.05)$, while with different small letter superscripts mean significant difference $(P<0.05)$.

\section{Discussion}

The trace minerals required for growth and development of piglets after weaning are mainly from innate reserves and diets. Due to the incomplete development of intestinal and low feed intake within a period of time after weaning, the trace minerals taken by piglets from the diet are limited. Therefore, providing the piglets with higher bio-available trace minerals may be an effective method to reduce the amount of trace minerals used. In our study, we evaluated the effects of low-dose glycine-complexed trace minerals replacing ITM in piglets. maximize growth performance. The growth-promoting mechanism of trace minerals as $\mathrm{Cu}$ and $\mathrm{Zn}$ is mainly that 

mucosa of piglets is susceptible to damage due to conversion from milk to solid feed after weaning. The pigs treated with glycine-complexed trace minerals had more intact intestinal villi in that the jejunum microvilli of pigs in $\mathrm{T} 3$ and $\mathrm{T} 4$ were more serried than that in $\mathrm{T} 1$. We speculated that this may be due to the fact that glycine from complex can promote protein synthesis in intestinal epithelial cells and reduce epithelial cell apoptosis [17]. and globulin, and their levels are important indicators of serological examinations, and they are generally affected by the concentration of dietary protein and disease. In our study, supplemental low-dose OTM from

GCM did not cause significant changes in serum total protein and albumin, which may indicate that metal compared to trace mineral sulfates, glycine-complexed trace minerals provide glycine while providing trace elements, but this seems to be negligible for nitrogen metabolism. Alkaline phosphatase is one of the biochemical indicators for evaluating the inflammation in the liver and kidneys [18]. The study of its structure found that ALP contains 2 binding sites of $\mathrm{Zn}^{2+}$, and $\mathrm{Zn}^{2+}$ are not free to enter and exit the ALP due to the presence of Glu49 residue [19]. That may explain that the difference of zinc ion concentration did not affect the 
normal function of the liver and kidney. After absorption by intestinal epithelial cells, the iron in the diet enters the plasma and binds with transferrin to participate in the transport [20]. The total iron-binding capacity reflects the maximum amount of iron that can be bound by transferrin, which actually indicates the level of serum transferrin. In our study, there was no significant difference of transferrin and total iron binding capacity among the 4 treatments, indicating that the amount of iron involved in body transport was not affected by dietary iron concentrations. However, in serum ferritin, which implicates serum iron storage capacity, we found that T2 had significantly higher serum ferritin concentration than $\mathrm{T} 3$ and $\mathrm{T} 4$. This indicates that the total amount of iron entering the serum is still affected by the trace minerals concentration of the diet, while low-dose treatments had no significant difference in serum ferritin compared to the control treatment, which may prove that glycine complexed iron has a higher digestibility than the ferrous sulfate. Ceruloplasmin is a ferroxidase that contains greater than $95 \%$ of the copper found in plasma. It appears to have more than one functional role in mammalian metabolism such as copper transport and antioxidant defense [21]. It is also considered to be a positive acute phase protein in pigs, so the activity of ceruloplasmin can be used to reflect whether the animal is in a normal physiological state [22,23]. In our study, the activity of ceruloplasmin was not affected by different concentrations of $\mathrm{Cu}^{2+}$ in the diet, whereas in Feng's study [24], the high copper diet significantly increased the activity of ceruloplasmin, which may be related to the considerable difference in the amount of copper added in the two experiments. It is worth mentioning that our results are consistent with the findings of Creech's study [25], which has the similar copper doses.

Serum antibodies are the essential component of innate and adaptive immunity and immunological memory. They also contribute significantly to immunopathology [26]. In this study, serum immunoglobulins (IgA, IgG, and IgM) and complements 3 and 4 were not affected by the level and source of trace minerals, which is similar to the results of Feng's research [27] in which piglets were fed with iron glycine chelate. This indicates that the 
minimum treatment dose in this study was not sufficient to affect humoral immunity. The weaning process of

piglets is often accompanied by inflammation, which can trigger up-regulation of pro-inflammatory cytokines

that can damage the mucosal barrier and intestinal permeability, such as TNF- $\alpha$, IL-6. In Pu's study [28],

supplementation iron dextran to newborn piglets reduced the expression of inflammatory factors TNF- $\alpha$ and IL-6

mRNA, confirming that iron supplementation can alleviate the increase in inflammatory factors caused by iron

deficiency. In present study, we found that serum concentrations of pro-inflammatory factors (TNF- $\alpha$, IL-6) and microorganisms. Through a process known as immune exclusion, sIgA promotes the clearance of antigens and pathogenic microorganisms from the intestinal lumen by blocking their access to epithelial receptors, entrapping them in mucus, and facilitating their removal by peristaltic and mucociliary activities $[29,30]$. In

Fig. 1C, only ileal sIgA exhibited significant differences between the treatments, and the concentration of sIgA in mucosa of $\mathrm{T} 2$ was significantly higher than that of $\mathrm{T} 1$, suggesting that glycine complexed trace minerals can improve intestinal mucosal immunity in piglets. A similar study by Levkut did not find that jejunal sIgA concentrations in broilers were affected by dietary concentrations of $\mathrm{ZnSO}_{4}$ and Gly- $\mathrm{Zn}$ [31].

The intestinal mucosa is formed by monolayer columnar epithelium cells, performing the primary functions in digesting, absorbing of nutrients, and preventing luminal pathogens and toxic substances cause any damage.

Early weaning stress syndrome usually leads to a decrease in $\mathrm{VH}$ and intestinal dysfunction in piglets. Impaired intestinal epithelial function disrupts immune homeostasis and increases inflammation, disturbing the intestinal barrier function, unbalancing absorptive-secretory electrolytes, and leading to fluid and diarrhea [32]. Payne reported that jejunum $\mathrm{VH}$ of weanling pigs from sows fed $\mathrm{ZnSO}_{4}$ or $\mathrm{Zn}-\mathrm{AA}$ was greater than those from sows 
of broilers [34]. In our results, the duodenum $\mathrm{VH}$ of the piglets in the $70 \% \mathrm{GCM}$ treatment was increased, indicating that the higher concentrations of GCM are positive for the intestinal epithelium cells. The results of optical microscopy and electron microscopy $(\times 150)$ also showed that the jejunum villi morphology in $\mathrm{T} 3$ and T4 were more intact. At 20,000× magnification, the jejunum villi of T3 and T4 were also denser. This may be related to the nutritional function of glycine in the GCM discussed above.

The intact intestinal villus morphology not only reduces local inflammation and diarrhea in the intestine, but also facilitates the absorption of nutrients. In the apparent total tract digestibility of trace minerals, glycine complexed trace minerals exhibited higher digestibility than inorganic trace minerals, and there were significant differences in iron and zinc. ZnT1, Fpn1 and Ctr1 are specific transporters of zinc, iron and copper, respectively. $\mathrm{ZnT} 1$ is located in the basolateral membrane of intestinal epithelial cells, transporting $\mathrm{Zn}^{2+}$ absorbed into intestinal epithelial cells into capillaries [35,36]. Fpn1 is also located in the basolateral membrane of small intestinal epithelial cells, oxidized $\mathrm{Fe}^{2+}$ into $\mathrm{Fe}^{3+}$ in coordination with ferrous oxidase (HP), and transported to plasma for binding with transferrin [37,38]. Ctr1 is located in the cell membrane of small intestinal epithelial cells, and $\mathrm{Cu}^{2+}$ first binds it and then enter into intestinal epithelial cells [39-41]. DMT1 is a divalent metal transporter, participating in the absorption of dietary divalent metal ions $\left(\mathrm{Fe}^{2+}, \mathrm{Mn}^{2+}\right.$, etc. $)$ in the small intestine epithelium, and transporting metal ions from the digestive tract into the blood [42]. By further measuring the expression of metal transporter mRNA in the duodenal mucosa, we found that the increase expression of ZnT1 and Fpn1 mRNA in T4 was consistent with the aforementioned high apparent digestibility. These two results demonstrate that the digestibility of glycine complexed iron and zinc is higher than that of inorganic iron and zinc. In the two treatments supplemented with $100 \%$ trace minerals, there was no significant difference in ATTD 
emissions than T1 (except Mn), the concentration of urine zinc and urine iron in T2 was significantly lower than

that in T1. Since the digestibility of glycine complexed trace minerals is higher than that of inorganic trace minerals, compared with $100 \%$ ITM treatment, $50 \%$ ITM $+50 \%$ GCM treatment has more metal ions absorbed into the body, while the excretions were also lower. This indicates that glycine complexed trace minerals have higher bioavailability and are more easily selected for storage. Although the metal excretions of T3 and T4 were lower, it is difficult to conclude whether this was due to the difference in the amount of addition or bioavailability.

\section{Conclusion}

Under the current trial conditions, our results indicate that glycine-complexed minerals have higher bioavailability than inorganic trace minerals; supplementation of low-dose GCM to replace ITM could reduce fecal minerals excretion without affecting performance, blood profiles, immune responses and intestinal morphology in piglets.

\section{Ethics approval and consent to participate}

All procedures applied in this study were approved by the Zhejiang University Institution Animal Care and Use Committee and were conducted in accordance with the National Institutes of Health guidelines for the care and use of experimental animals.

\section{Consent for publication}

All authors read and approved the final manuscript.

\section{Availability of data and materials}

All data generated or analyzed during this study are included in this article.

\section{Competing interests}




\section{Funding}

This research is financially supported by Three Agricultural and Six-Party Research Cooperation Project of

Zhejiang Province, China (No. CTZB-F180706LWZ-SNY1).

\section{Author contributions}

Minqi Wang conceived and designed the whole scheme of the experiments. Xun Pei, Geng Wang conducted

357

358

the experiments. Lujie Liu and Wanjing Sun participated in the determination of experimental indexes. Zhiping

Xiao and Wenjing Tao helped analyze and interpret the experimental data. Mingyan Huai provided glycine complexed trace minerals. Xun Pei wrote the manuscript. Mingyan Huai, Lily Li and Wolf Pelletier revised and copy-edited the manuscript.

\section{Acknowledgments}

We sincerely thank Anji Zhengxin Animal Husbandry Co.,Ltd, Zhejiang, China for providing the feeding ground and weaned piglets. We would like to thank Shunxin Shen and Qiuming Shen for the support of feeding and management of piglets.

\section{Reference}

1. Underwood EJ, The mineral nutrition of livestock. CABI Publishing, New York. 1999.

2. NRC, Nutrient requirements of swine. Natl Acad Press, Washington. 2012.

3. Martin R, Mahan D, Hill G, Link J and Jolliff J, Effect of dietary organic microminerals on starter pig performance, tissue mineral concentrations, and liver and plasma enzyme activities. J Anim Sci. 2011; 89:1042-1055.

4. Ettle T, Schlegel P and Roth FX, Investigations on iron bioavailability of different sources and supply levels in piglets. J Anim Physiol an N. 2008; 92:35-43.

5. Richards JD, Zhao JM, Harrell RJ, Atwell CA and Dibner JJ, Trace Mineral Nutrition in Poultry and Swine. Asian Austral J Anim. 2010; 23:1527-1534.

6. Nitrayova S, Windisch W, von Heimendahl E, Muller A and Bartelt J, Bioavailability of zinc from different sources in pigs. J Anim Sci. 2012; 90:185-187. 
7. Liu Y, Ma YL, Zhao JM, Vazquez-Anon M and Stein HH, Digestibility and retention of zinc, copper, manganese, iron, calcium, and phosphorus in pigs fed diets containing inorganic or organic minerals. J Anim Sci. 2014; 92:3407-3415.

8. Shen YB, Piao XS, Kim SW, Wang L, Liu P, Yoon I and Zhen YG, Effects of yeast culture supplementation on growth performance, intestinal health, and immune response of nursery pigs. $\mathrm{J}$ Anim Sci. 2009; 87:2614-2624 (2009).

9. Gao Y, Han F, Huang X, Rong Y, Yi H and Wang Y, Changes in gut microbial populations, intestinal morphology, expression of tight junction proteins, and cytokine production between two pig breeds after challenge with Escherichia coli K88: A comparative study. J Anim Sci. 2013; 91:5614-5625.

10. Huang DP, Zhuo Z, Fang SL, Yue M and Feng J, Different Zinc Sources Have Diverse Impacts on Gene Expression of Zinc Absorption Related Transporters in Intestinal Porcine Epithelial Cells. Biol Trace Elem Res. 2016; 173:325-332.

11. Livak KJ and Schmittgen TD, Analysis of relative gene expression data using real-time quantitative PCR and the 2(T)(-Delta Delta C) method. Methods. 2001; 25:402-408.

12. Hill GM, Cromwell GL, Crenshaw TD, Dove CR, Ewan RC, Knabe DA, Lewis AJ, Libal GW, Mahan DC, Shurson GC, Southern LL, Veum TL, Comm NRSN and Comm SRSN, Growth promotion effects and plasma changes from feeding high dietary concentrations of zinc and copper to weanling pigs (regional study). J Anim Sci. 2000; 78:1010-1016.

13. Jongbloed AW, Bikker P and Thissen J, Dose-response relationships between dietary copper level and growth performance in piglets and growing-finishing pigs and effect of withdrawal of a high copper level on subsequent growth performance, Ed. Wageningen UR Livestock Research. 2011.

14. Perez VG, Waguespack AM, Bidner TD, Southern LL, Fakler TM, Ward TL, Steidinger M and Pettigrew JE, Additivity of effects from dietary copper and zinc on growth performance and fecal microbiota of pigs after weaning. J Anim Sci. 2011; 89:414-425.

15. Zhu D, Yu B, Ju C, Mei S and Chen D, Effect of high dietary copper on the expression of hypothalamic appetite regulators in weanling pigs. J Anim Feed Sci. 2011; 20:60-70.

16. Feng J, Ma WQ, Niu HH, Wu XM, Wang Y and Feng J, Effects of Zinc Glycine Chelate on Growth, Hematological, and Immunological Characteristics in Broilers. Biol Trace Elem Res. 2011; 133:203-211.

17. Wang WW, Wu ZL, Lin G, Hu SD, Wang B, Dai ZL and Wu GY, Glycine Stimulates Protein Synthesis and Inhibits Oxidative Stress in Pig Small Intestinal Epithelial Cells. J Nutr. 2014; 144:1540-1548.

18. Wang L, Xu ZR, Jia XY and Han XY, Effects of dietary arsenic levels on serum parameters and trace mineral retentions in growing and finishing pigs. Biol Trace Elem Res. 2006; 113:155-164.

19. Millan J, Alkaline phosphatases structure, substrate specificity and functional relatedness to other members of a large superfamily of enzymes. Purinerg Signal. 2006; 2:335-341.

20. Lopez A, Cacoub P, Macdougall IC and Peyrin-Biroulet L, Iron deficiency anaemia. Lancet. 2016; 387:907-916.

21. Martinez-Subiela S, Tecles F and Ceron JJ, Comparison of two automated spectrophotometric methods for ceruloplasmin measurement in pigs. Res Vet Sci. 2007; 83:12-19.

22. Eckersall P, Saini P and McComb C, The acute phase response of acid soluble glycoprotein, $\alpha 1$-acid glycoprotein, ceruloplasmin, haptoglobin and C-reactive protein, in the pig. Vet Immunol Immunop. 1996; 51:377-385.

23. Skinner JG and Grp ECA, International standardization of acute phase proteins. Vet Clin Path. 2001; $30: 2-7$. 
24. Feng J, Ma WQ, Gu ZL, Wang YZ and Liu JX, Effects of dietary copper (II) sulfate and copper proteinate on performance and blood indexes of copper status in growing pigs. Biol Trace Elem Res. 2007; 120:171-178.

25. Creech BL, Spears JW, Flowers WL, Hill GM, Lloyd KE, Armstrong TA and Engle TE, Effect of dietary trace mineral concentration and source (inorganic vs. chelated) on performance, mineral status, and fecal mineral excretion in pigs from weaning through finishing. J Anim Sci. 2004; 82:2140-2147.

26. Manz RA, Hauser AE, Hiepe F and Radbruch A, Maintenance of serum antibody levels. Annu Rev Immunol. 2005; 23:367-386.

27. Feng J, Ma WQ, Xu ZR, Wang YZ and Liu JX, Effects of iron glycine chelate on growth, haematological and immunological characteristics in weanling pigs. Anim Feed Sci Tech. 2007; 134:261-272.

28. Pu YT, Guo BX, Liu D, Xiong HT, Wang YZ and Du HH, Iron Supplementation Attenuates the Inflammatory Status of Anemic Piglets by Regulating Hepcidin. Biol Trace Elem Res. 2015; 167:28-35.

29. Keren DF, Intestinal Mucosal Immune Defense-Mechanisms. Am J Surg Pathol. 1988; 12:100-105.

30. Mantis NJ, Rol N and Corthesy B, Secretory IgA's complex roles in immunity and mucosal homeostasis in the gut. Mucosal Immunol. 2011; 4:603-611.

31. Levkut M, Husáková E, Bobíková K, Karaffová V, Levkutová M, Ivanišinová O, Grešáková L', Čobanová K, Reiterová K and Levkut M, Inorganic or organic zinc and MUC-2, IgA, IL-17, TGF- $\beta 4$ gene expression and sIgA secretion in broiler chickens. Food Agr Immunol. 2017; 28:801-811.

32. Blachier F, Wu G and Yin Y, Nutritional and physiological functions of amino acids in pigs. Springer. 2013.

33. Payne RL, Bidner TD, Fakler TM and Southern LL, Growth and intestinal morphology of pigs from sows fed two zinc sources during gestation and lactation. J Anim Sci. 2006; 84:2141-2149.

34. Ma WQ, Niu HH, Feng J, Wang Y and Feng J, Effects of Zinc Glycine Chelate on Oxidative Stress, Contents of Trace Elements, and Intestinal Morphology in Broilers. Biol Trace Elem Res. 2011; 142:546-556.

35. Lichten LA and Cousins RJ, Mammalian Zinc Transporters: Nutritional and Physiologic Regulation. Annu Rev Nutr. 2009; 29:153-176.

36. Gefeller EM, Bondzio A, Aschenbach JR, Martens H, Einspanier R, Scharfen F, Zentek J, Pieper R and Lodemann U, Regulation of intracellular $\mathrm{Zn}$ homeostasis in two intestinal epithelial cell models at various maturation time points. J Physiol Sci. 2015; 65:317-328.

37. Donovan A, Brownlie A, Zhou Y, Shepard J, Pratt SJ, Moynihan J, Paw BH, Drejer A, Barut B, Zapata A, Law TC, Brugnara C, Kingsley PD, Palis J, Fleming MD, Andrews NC and Zon LI, Positional cloning of zebrafish ferroportin1 identifies a conserved vertebrate iron exporter. Nature. 2000; 403:776-781.

38. Ma WQ, Lu JY, Jiang SX, Cai DM, Pan SF, Jia YM and Zhao RQ, Maternal protein restriction depresses the duodenal expression of iron transporters and serum iron level in male weaning piglets. Brit J Nutr. 2017; 117:923-929.

39. Nose Y, Kim BE and Thiele DJ, Ctr1 drives intestinal copper absorption and is essential for growth, iron metabolism, and neonatal cardiac function. Cell Metab. 2006; 4:235-244.

40. Kaplan JH and Lutsenko S, Copper Transport in Mammalian Cells: Special Care for a Metal with Special Needs. J Biol Chem. 2009; 284:25461-25465.

41. Wang YF, Hodgkinson V, Zhu S, Weisman GA and Petris MJ, Advances in the Understanding of Mammalian Copper Transporters. Adv Nutr. 2011; 2:129-137. 
42. Garrick MD, Dolan KG, Horbinski C, Ghio AJ, Higgins D, Porubcin M, Moore EG, Hainsworth LN, Umbreit JN, Conrad ME, Feng L, Lis A, Roth JA, Singleton S and Garrick LM, DMT1: A mammalian transporter for multiple metals. Biometals. 2003; 16:41-54.

468 
Table 1. Composition and nutrient levels of the basal diet (as-fed basis)

\begin{tabular}{|c|c|c|}
\hline Ingredients / nutrient level (\%) & Phase I (0-14d) & Phase II (15-28d) \\
\hline Corn & 43.0 & 64.5 \\
\hline Expanded soybean & 7.5 & 0 \\
\hline Expanded rice & 8.0 & 0 \\
\hline Fermented soybean meal & 7.5 & 7.5 \\
\hline Soybean meal & 0 & 11.0 \\
\hline Fish meal & 3.0 & 3.0 \\
\hline Wheat flour & 5.0 & 5.0 \\
\hline Cheese powder & 2.5 & 2.5 \\
\hline Spray dried blood meal & 2.0 & 0 \\
\hline Intestinal membrane protein & 2.5 & 0 \\
\hline Dried whey & 7.5 & 0 \\
\hline Sucrose & 7.5 & 2.5 \\
\hline Calcium citrate & 1.2 & 1.2 \\
\hline $\mathrm{CaHPO}_{4}$ & 0.6 & 0.6 \\
\hline $\mathrm{NaCl}$ & 0.2 & 0.2 \\
\hline Titanium dioxide & 0.3 & 0.3 \\
\hline L-Lysine HC & 0.45 & 0.45 \\
\hline DL-Methionine & 0.05 & 0.05 \\
\hline L-Threonine & 0.2 & 0.2 \\
\hline L- Tryptophan & 0.05 & 0.05 \\
\hline Vitamine premix & 0.04 & 0.04 \\
\hline Trace minerals premix ${ }^{\dagger}$ & 0.5 & 0.5 \\
\hline Enzymes & + & + \\
\hline Antibiotics $^{\S}$ & + & + \\
\hline Total & 100 & 100 \\
\hline \multicolumn{3}{|l|}{ Nutrient level ${ }^{\pi} \%$} \\
\hline $\mathrm{CP}$ & 18.10 & 17.70 \\
\hline $\mathrm{EE}$ & 4.04 & 3.49 \\
\hline $\mathrm{CF}$ & 1.63 & 2.23 \\
\hline Lys & 1.42 & 1.32 \\
\hline Met & 0.36 & 0.36 \\
\hline $\mathrm{DE}\left(\mathrm{MJ} \mathrm{Kg}^{-1}\right)$ & 12.42 & 12.93 \\
\hline
\end{tabular}


Continued

\begin{tabular}{lll}
$\mathrm{Ca}$ & 0.73 & 0.69 \\
Total P & 0.56 & 0.54 \\
\hline
\end{tabular}

470

Provided as experimental design.

$471 \quad$ Natuphos E $10000,50 \mathrm{mg} \mathrm{ton}^{-1}$ feed.

472 \$ntibiotics supplemented in feed per ton: Enramycin $12 \mathrm{mg}$, Terramycin calcium $200 \mathrm{mg}$, Macleaya cordata 473 premix $500 \mathrm{mg}$, Gallotannic acid premix $500 \mathrm{mg}$;

474 "Analyzed data except DE.

475 
Figure 1. Effects of different levels of glycine complexed trace minerals on Serum and intestinal mucosal with “*” are significantly different $(P<0.05)$, whereas those with “**” are extremely significant different $(P<$ $0.01)$.

Figure 2. Microscopic observation of intestinal villus morphology and Measurements of villus height,

crypt depth, and villus height/crypt depth (V/C) in duodenum, jejunum. A. Histological photomicrographs

of duodenum section with optical microscopy, $\times 400$; B. Histological photomicrographs of jejunum section with crypt depth, and V/C in jejunum. Data are expressed as means \pm SEM $(n=6)$. Values with “*” are significantly different $(P<0.05)$, whereas those with “**” are extremely significant different $(P<0.01)$. 
Figures

A

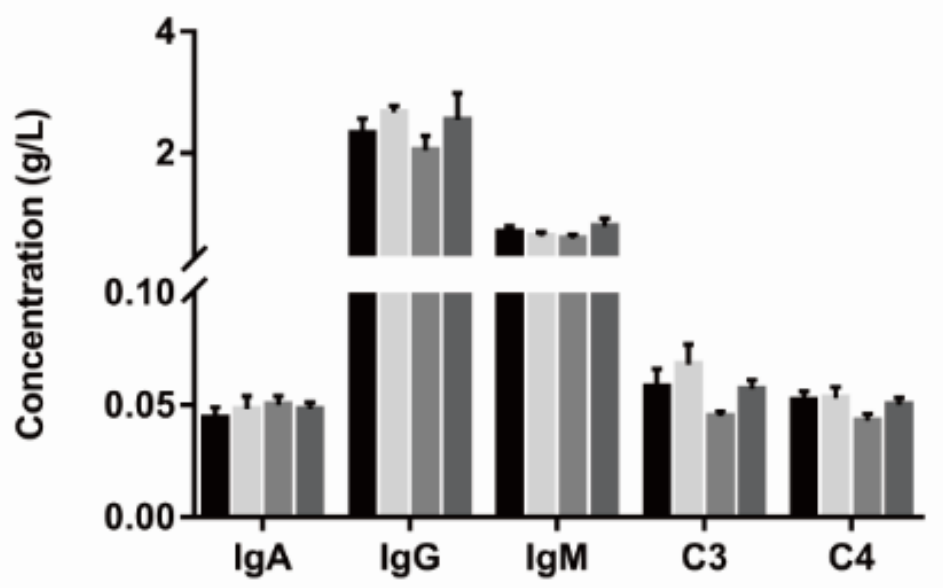

- $100 \%$ ITM

$50 \% \mathrm{ITM}+50 \% \mathrm{GCM}$

$50 \%$ GCM

$70 \% \mathrm{GCM}$

B

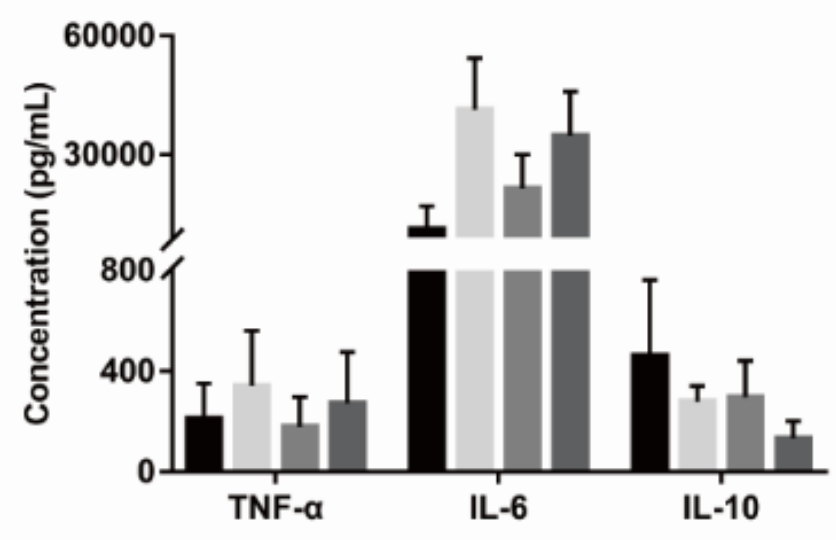

$\mathrm{C}$

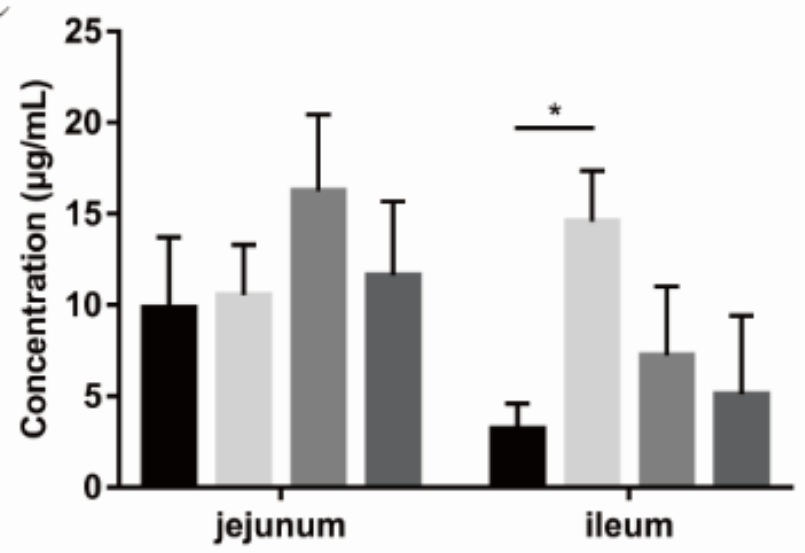

Figure 1

[Please see the manuscript to view the figure legend.] 

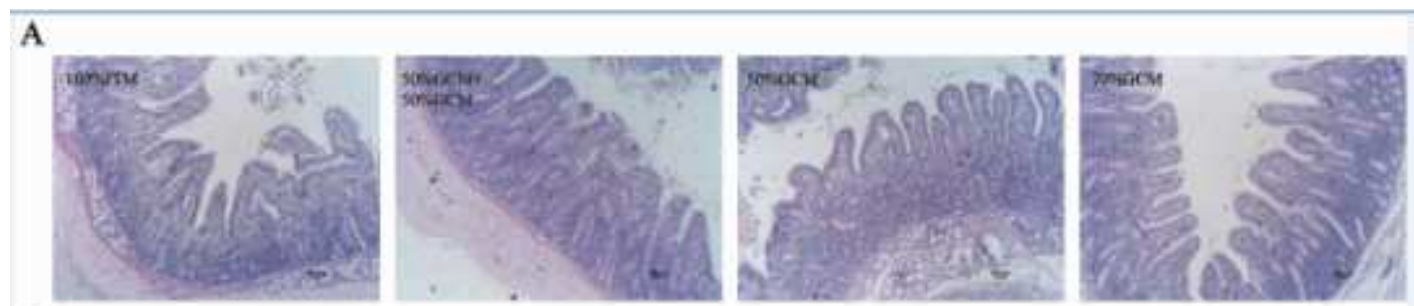

B
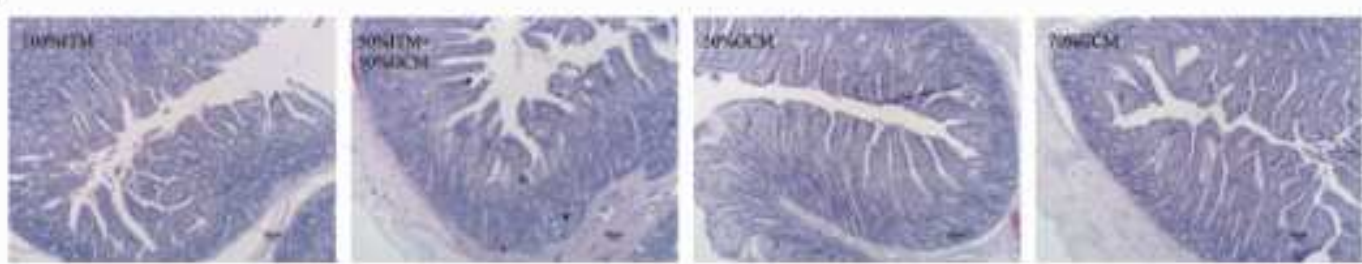

C

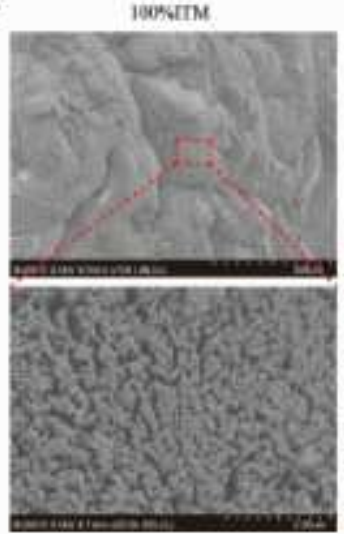

50\%4TM+S94XCM

sesuce

rasces
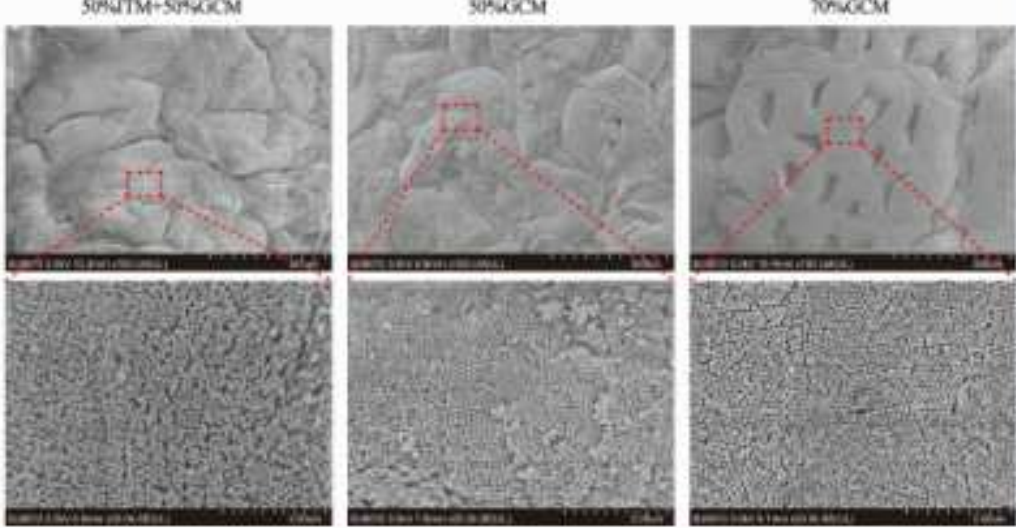

D

E

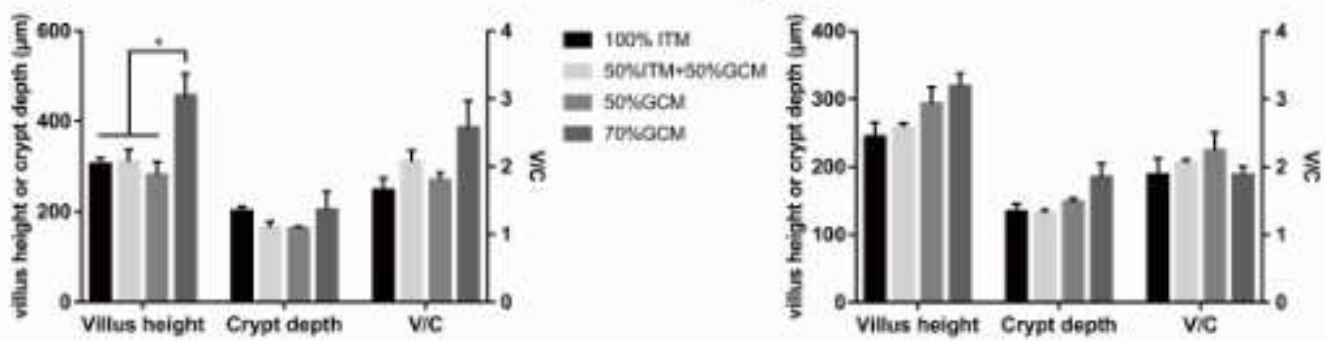

Figure 2

[Please see the manuscript to view the figure legend.] 


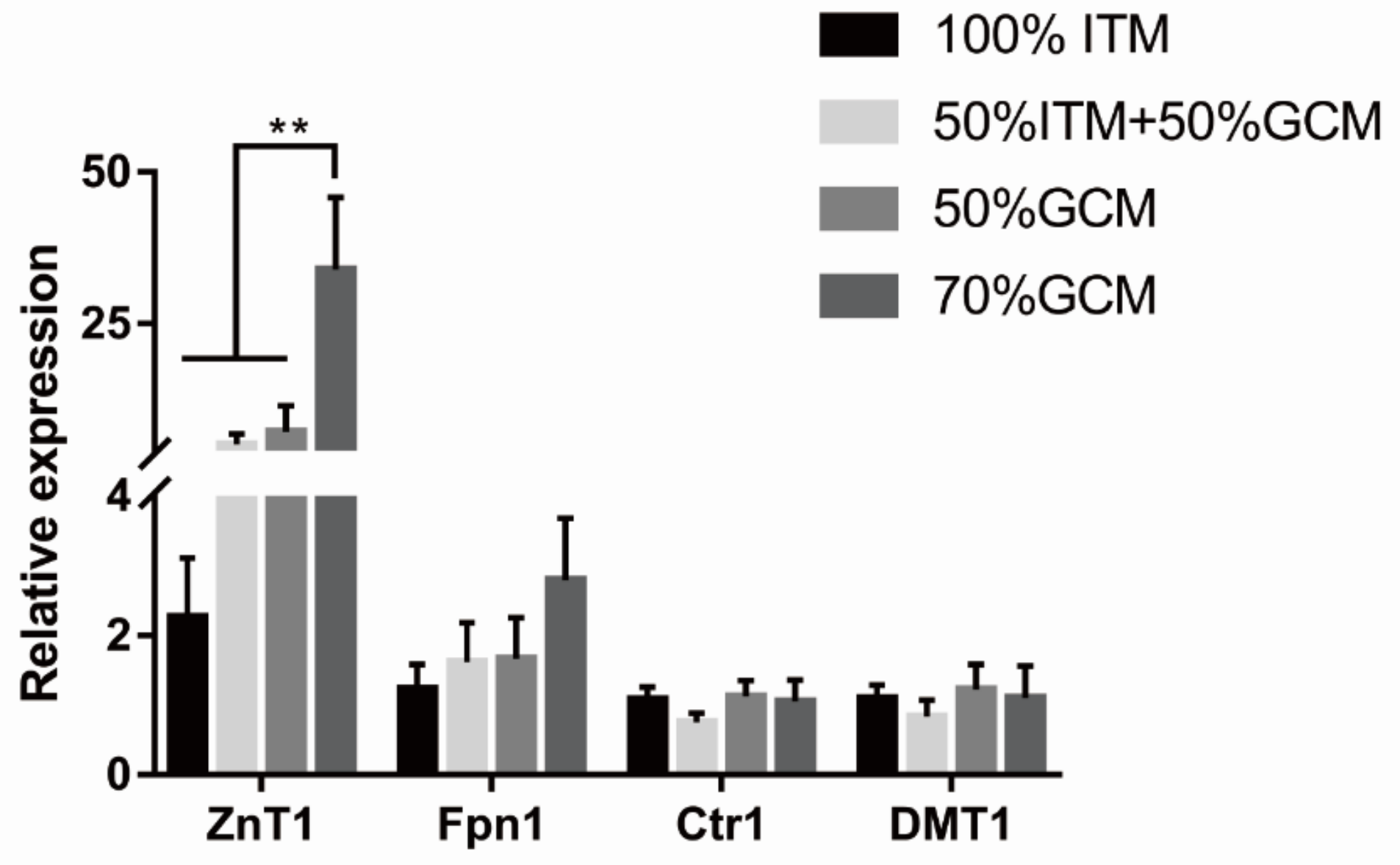

Figure 3

[Please see the manuscript to view the figure legend.] 